\title{
Genetic Analysis of Heat Adaptive Traits in Tropical Maize (Zea mays L.)
}

\author{
Krishnaji Jodage ${ }^{1}$, P.H. Kuchanur ${ }^{*}$, P.H. Zaidi ${ }^{3}$, Ayyanagouda Patil ${ }^{2}$, \\ K. Seetharam ${ }^{3}$, M.T. Vinayan ${ }^{3}$ and B. Arunkumar ${ }^{1}$ \\ ${ }^{1}$ Department of Genetics and Plant Breeding, University of Agricultural Sciences, \\ Raichur-584 104, Karnataka, India \\ ${ }^{2}$ Department of Molecular Biology and Agriculture Biotechnology, University of Agricultural \\ Sciences, Raichur-584104, Karnataka, India \\ ${ }^{3}$ International Maize and Wheat Improvement Center (CIMMYT) - Asia c/o ICRISAT, \\ Patancheru, Hyderabad-502324, Telangana, India \\ *Corresponding author
}

\section{A B S T R A C T}

\begin{tabular}{|l|}
\hline Ke y w o r d s \\
Zea mays L., \\
Gene action, \\
Heat tolerance, \\
LxT, NCD-II
\end{tabular}

Studies were conducted to determine the gene action for heat adaptive traits and grain yield under heat stress condition by using the hybrids generated in LxT and NCD-II. The results revealed predominance of non-additive gene action for heat stress adaptive traits in both the experiments. Among the parents, ZL135005 and CAL1730 of LxT experiment and ZL132088 and CZL0522 of NCD-II were good general combiners for heat tolerance component traits like leaf firing, tassel blast and also for yield contributing traits and hence these lines could be used for generating pedigree crosses for deriving second cycle inbreds. Hybrids viz., ZL134989×CML470 and ZL135003×CML 470 of L×T; VL1010963× ZL132070 and VL062655×CAL1427 of NCD-II showed desirable specific combining ability effects for maximum number of traits. These hybrids could be taken forward for multi-location testing under heat stress condition. Association studies revealed that plant height $(0.199,0.286)$ and number of grains per cob $(0.458,0.453)$ were positively associated with grain yield and ASI $(-0.113,-0.107)$ leaf firing $(-0.163)$ and tassel blast (0.165 ) were associated negatively with grain yield. Tassel blast and leaf firing could be considered as negative traits for selection of tropical maize lines /hybrids under heat stress condition.

\section{Introduction}

Maize (Zea mays L.) is an important cereal crop worldwide, serving as a major staple for both human consumption and animal feed. It has also become a key resource for industrial applications and bio-energy production (Chen et al., 2012). Maize is one of the most versatile crops, due to its wider adaptability and higher productivity and hence grown over a wide range of environmental conditions. However, future global food security is at risk because of global climate change (Christensen and Christensen, 2007). Global climate changes have led to increased temperatures and increased frequency of droughts in some 
parts of the in some other parts of the globe leading to the occurrence of abiotic stresses in crops. globe and floods Abiotic stresses are often interrelated, either individually or in combination. They cause morphological, physiological, biochemical and molecular changes that adversely affect plant growth and productivity, and ultimately yield. Maize is highly productive under optimal environmental and crop management conditions, but susceptible to serve drought and extreme heat; each year, an average of $15 \%$ to $20 \%$ of the potential world maize production is lost due to these stresses (FAO STAT 20062008; Lobell et al., 2011). Further, it has been estimated that $2{ }^{\circ} \mathrm{C}$ increase in temperature above $30{ }^{\circ} \mathrm{C}$ reduces the maize yields by $13 \%$ as compared to $20 \%$ intra-seasonal variation in the rainfall, which reduces the maize yields by 4.5\% (Rowhani et al., 2011) and every degree increase in day temperature above $30{ }^{\circ} \mathrm{C}$ would decrease yield by $1 \%$ in optimum conditions and $1.7 \%$ in drought conditions (Lobell et al., 2011). In addition to the above, a record drop in global maize production due to heat waves has been reported (Cairns et al., 2012).

Maize plants become susceptible to high temperatures after reaching eight-leaf stage or V8 (Chen et al., 2010). Extremely high temperature causes permanent tissue injury to developing/young leaves and the injured tissues dry out quickly (a phenomenon known as leaf firing). It can also cause drying of complete tassel (or most of it) without pollen shedding, a phenomenon known as tassel blast. Under severe heat stress, leaf firing and tassel blast occur together. Plants with severe leaf firing and tassel blast lose considerable photosynthetic leaf area, produce very little pollen and small ears, and show reduced kernel set and kernel weight (Chen et al., 2012). Moderate heat stress occurring at early reproductive stages reduces pollen production, pollination rate, kernel set, and kernel weight, resulting in significant yield loss (Cantarero et al., 1999; Wilhelm et al., 1999). It has been suggested that each $1^{\circ} \mathrm{C}\left(1.8^{\circ} \mathrm{F}\right)$ increase in temperature above threshold could result in $1 \%$ to $2 \%$ and up to $3 \%$ to $4 \%$ of grain yield reduction (Shaw, 1983).

In view of this, there is a need to develop heat stress resilient maize hybrids to suit the changing climate. The study of genetic factors involved in plant responses to heat stress can provide a foundation for breeding maize with improved heat tolerance. Hence, it is essential to determine the genetics of heat adaptive traits and also yield and its components traits under heat stress condition by using different mating designs as the reports on these aspects are limited. This study aims to compare the results obtained by analysing the hybrids developed by using $\mathrm{L} \times \mathrm{T}$ as well as NCD-II designs with respect to gene action for various traits under heat stress and to identify good general and specific combiners for heat stress adaptive traits for future use in breeding programmes targeting improved heat tolerance in maize.

\section{Materials and Methods}

\section{Study site and experiment details}

The present investigation was carried out at Agriculture College Farm, Bheemarayanagudi $\left(16^{\circ} 44^{\prime} \mathrm{N}\right.$ latitude and $76^{\circ} 47^{\prime} \mathrm{E}$ longitude with an altitude of $458 \mathrm{~m}$ above mean sea level) during summer (mid-March to June), 2015. The experimental material consisted of two sets of hybrids; one set (86 hybrids) was developed using 43 tropical female lines (elite lines but reaction of these lines to heat stress was not known) crossed with two testers (Table 1) in $\mathrm{L} \times \mathrm{T}$ design (experiment-I). In another set, 49 hybrids were developed using seven tropical female and seven male lines (Table 2) by crossing in NCD-II design (experiment-II). These hybrids were 
developed at CIMMYT- Asia regional programme, ICRISAT campus, Patancheru, Hyderabad, India. Each entry was planted in one row plot of $4.0 \mathrm{~m}$ length at a spacing of 60 $\mathrm{cm} \times 20 \mathrm{~cm}$. Recommended agronomic practices were adopted to raise a healthy crop under drip irrigation. The hybrids (without parents) were evaluated in alpha-lattice design with two replications under natural heat stress condition by delayed plating (in mid-March) during Spring season.

\section{Data collection and analysis}

Anthesis and silking dates and ears per plot were recorded on per plot basis, whereas, plant height $(\mathrm{cm})$, ear height $(\mathrm{cm})$, number of grains per cob, ear length $(\mathrm{cm})$, ear girth $(\mathrm{cm})$, test weight $(\mathrm{g})$ and shelling per cent were recorded on five randomly selected representative plants in each plot. The sample cobs were shelled, cleaned and grain weight and shank weight were recorded to calculate the shelling per cent. Test weight was measured by counting 100 grains from the bulk of each plot after shelling and weighed in grams after the moisture was adjusted to $12.5 \%$.

Anthesis to silking interval (ASI) was calculated by subtracting the number of days taken for $50 \%$ anthesis from the number of days taken to $50 \%$ silk emergence. Leaf firing was recorded by the counting the number of plants that showed leaf firing symptoms (younger leaves near tassel burnt or dried) in the total number of plants in a particular plot, and expressed in percentage. Similarly, tassel blast was obtained by the counting the number of plants that showed tassel blast symptoms (tassel dried with partial or no pollen shedding) in the total number of plants in particular plot and expressed in percentage. Grain yield per plant (g) was calculated by dividing the grain yield per plot by total number of plants in the plot.
The estimates of general combining ability for females and males and specific combining ability for crosses were estimated as per Kempthorne (1957) in Experiemnt-I and Comstock and Robinson (1952) in Experiment-II, separately. The phenotypic correlation coefficients for various characters were calculated as per the method suggested by Al-Jibouri et al., (1958) for both the experiments using WINDOSTAT 9.2.

Weather data during crop growth period indicated that the most of the cropping period was under heat stress as indicated by the prevalence of high temperature (Tmax $>35^{\circ} \mathrm{C}$ and Tmin $\left.>22{ }^{\circ} \mathrm{C}\right)$ and low RH $(<40 \%)$ leading to proper evaluation of hybrids under heat stress. Further, Vapour Pressure Deficit (VPD) was also calculated (Abtew and Melesse, 2013) to measure drying power of the air around crop canopy which plays a key role in the overall effect of high temperatures on plant tissues as it indicates the deficit between the amount of moisture present in the air at a given air temperature and the amount of moisture the air can hold when it is fully saturated (Zaidi et al., 2016).

VPD at experimental site was $>3.00 \mathrm{kPa}$ and thus indicating heat stress during $8^{\text {th }}, 9^{\text {th }}$ and $10^{\text {th }}$ weeks which coincided with flowering period of the crop (Table 3 ).

\section{Results and Discussion}

Analysis of variance for combining ability revealed that variance due to lines was highly significant for anthesis date, silking date, plant height, ear height and ear length. Variance due to testers was highly significant for all the traits, except leaf firing, ear length, shelling percentage and grain yield per plant. Female $x$ male interaction variance was highly significant for tassel blast, ear girth and number of grains per cob in experiment-I (L×T experiment, data not shown). 
In experiment-II (NCD-II), variance due to female was highly significant for tassel blast, leaf firing, shelling percentage, test weight and grain yield per plant. Variance due to male was highly significant for all traits, except anthesis date, anthesis to silking interval, shelling per cent and grain yield per plant. Female $\times$ male interaction variance was highly significant for anthesis date, shelling percentage and grain yield per plant (data not shown).

Variances due to SCA were higher than the GCA variances for all the traits indicating preponderance of non-additive gene action in the inheritance of these traits in both the experiments (Table 4). This fact was supported by low GCA variance to SCA variance ratio. The inheritance of traits under heat stress in both the experiments was similar for all traits under study. Predominance of non-additive gene action for plant height, ear height, anthesis date, silking date, leaf firing, tassel blast was in accordance with the results of Rupinderkaur et al., (2010). Similarly, predominance of non-additive gene action for anthesis date, silking date and $75 \%$ brown husk maturity (Tassawer et al., 2007) and for plant height, tassel blast and leaf firing (Dinesh et al., 2016) have been reported. This suggests the importance of non-additive gene action in expression of these traits and further the opportunity for exploitation of heterosis for improving heat stress tolerance in maize.

\section{General combining ability effects}

Estimates of general combining ability $(g c a)$ effects of parents of both the experiments are presented in Table 5. In experiment-I, parents viz., ZL135005 possessed desirable gca effects for ear height (9.02), ear girth (0.97), number of grains per cob (71.60) and grain yield (33.64) and CAL1730 for plant height (21.51), ear height (10.02), and number of grains per cob (55.85). Among the testers, CML 472 was good general combiner for ASI (-0.90), tassel blast (-20.57, plant height (9.57) and test weight (1.76). In experiment- II, ZL132088 and CZL0522 were good general combiners for tassel blast (-8.11) and shelling percentage (3.98), respectively. Among the testers, CAL14113 was a good general combiner for grain yield (13.13) and ear length (1.16). Use of these parents in breeding programme would be effective to commercially exploit nonadditive genetic variation for heat tolerance traits and also grain yield in spring maize by developing heat tolerant hybrids.

\section{Specific combining ability effects}

The crosses with highly positive and significant estimates of sca effects could be selected for their specific combining ability to use in maize improvement program (Abrha et $a l$. , 2013). The specific combining ability effects of all the crosses were considered and top three hybrids were selected among the crosses for selected traits based on their sca effects and presented in Table 6.

In experiment-I, ZL135007 × CML 470 was a superior hybrid, which showed desired sca effects for the traits viz., tassel blast (-33.12), leaf firing (-16.86) and grain yield (18.78). Another hybrid in the same experiment, ZL135003 $\times$ CML470 exhibited desirable sca effects for number of grains per cob (78.81) and test weight (6.66). Hybrid, ZL134993 × CML 472 was a high yielding hybrid (27.21) which also exhibited desirable sca effects for number of grains per cob (67.69).

In experiment-II, CZL0522 × CAL 1427 was a desirable cross as it recorded desirable sca effects for most of the traits viz., plant height (18.31), number of grains per cob (71.95), test weight (3.68), grain yield per plant (24.93) as well as heat tolerance and it could be used as a high yielding, heat tolerant and tall stature hybrid (Table 6). 
Table.1 List of inbred lines used as parents in generating 86 hybrids using LxT design (Experiment- I)

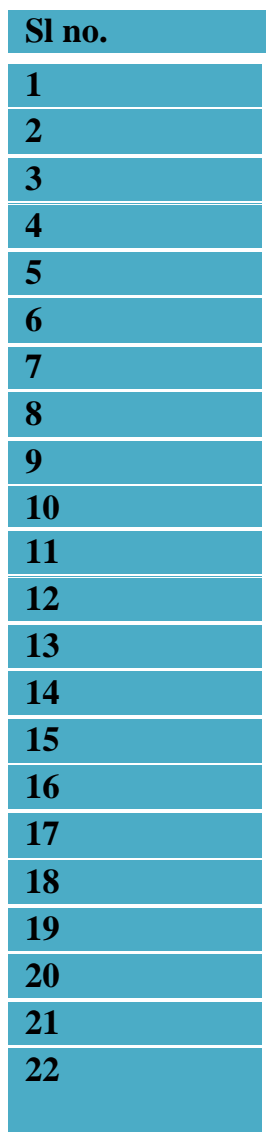

\begin{tabular}{|l|l|}
\hline Parents \\
\hline ZL135016 \\
\hline ZL135019 \\
\hline ZL135020 \\
\hline ZL135021 \\
\hline ZL135022 \\
\hline ZL135023 \\
\hline ZL135025 \\
\hline ZL135009 \\
\hline ZL135027 \\
\hline ZL135031 \\
\hline ZL135033 \\
\hline ZL135035 \\
\hline ZL135011 \\
\hline ZL135012 \\
\hline ZL134979 \\
\hline ZL134982 \\
\hline ZL134983 \\
\hline ZL134985 \\
\hline ZL134986 \\
\hline ZL134988 \\
\hline ZL134989 \\
\hline ZL135007 \\
\hline
\end{tabular}

\begin{tabular}{|l|l|}
\hline SI no. & Parents \\
\hline 23 & ZL135006 \\
\hline 24 & ZL135001 \\
\hline 25 & ZL135003 \\
\hline 26 & ZL135004 \\
\hline 27 & ZL135005 \\
\hline 28 & ZL134993 \\
\hline 29 & CAL1728 \\
\hline 30 & ZL134996 \\
\hline 31 & CAL1729 \\
\hline 32 & ZL134998 \\
\hline 33 & ZL134999 \\
\hline 34 & ZL135055 \\
\hline 35 & ZL135056 \\
\hline 36 & ZL135066 \\
\hline 37 & ZL135091 \\
\hline 38 & ZL135093 \\
\hline 39 & ZL135097 \\
\hline 40 & CAL1730 \\
\hline 41 & ZL135041 \\
\hline 42 & ZL135045 \\
\hline 43 & ZL135047 \\
\hline Testers & $1 . C M L 472$ \\
\hline & 2. CML470 \\
\hline
\end{tabular}

Table.2 List of inbred lines used as parents in generating 49 hybrids using NCD-II design (Experiment- II)

\begin{tabular}{|c|c|l|}
\hline Parental lines & Pedigree & Reaction to heat stress \\
\hline L1 & VL1010963 & Tolerant \\
\hline L2 & ZL132088 & Tolerant \\
\hline L3 & CAL1510 & Tolerant \\
\hline L4 & VL062655 & Tolerant \\
\hline L5 & ZL14115 & Tolerant \\
\hline L6 & CAL14135 & Tolerant \\
\hline L7 & CZL0522 & Tolerant \\
\hline T1 & CAL1427 & Susceptible \\
\hline T2 & ZL132200 & Susceptible \\
\hline T3 & ZL132070 & Tolerant \\
\hline T4 & CZL0611 & Tolerant \\
\hline T5 & CIL1218 & Susceptible \\
\hline T6 & CAL14113 & Susceptible \\
\hline T7 & CAL1722 & Tolerant \\
\hline
\end{tabular}


Table.3 Meteorological data for the cropping period (2015) recorded at the meteorological observatory of the Agricultural Research Station, Bheemarayanagudi

\begin{tabular}{|c|c|c|c|c|c|c|c|}
\hline \multirow[t]{2}{*}{ Month } & \multirow{2}{*}{$\begin{array}{l}\text { Stage of the } \\
\text { crop (week) }\end{array}$} & \multirow{2}{*}{$\begin{array}{l}\text { Rainfall } \\
\text { (mm) }\end{array}$} & \multicolumn{2}{|c|}{ Temperature $\left({ }^{0} \mathrm{C}\right)$} & \multicolumn{2}{|c|}{ Relative humidity (\%) } & \multirow{2}{*}{$\begin{array}{c}\text { VPD (kPa) } \\
\text { @ Max. Temp. and } \\
\text { Min. RH }\end{array}$} \\
\hline & & & Maximum & Minimum & $8.30 \mathrm{AM}$ & 5.30 PM & \\
\hline \multirow[t]{4}{*}{ March } & $1^{\text {st }}$ week & 2.79 & 32.57 & 19.86 & 67.14 & 44.14 & 2.66 \\
\hline & $2^{\text {nd }}$ week & 2.86 & 32.29 & 21.00 & 67.00 & 53.43 & 2.22 \\
\hline & $3^{\text {rd }}$ week & 0.00 & 35.14 & 21.29 & 64.00 & 49.29 & 2.85 \\
\hline & $4^{\text {th }}$ week & 0.00 & 35.57 & 20.71 & 67.43 & 47.43 & 2.96 \\
\hline \multirow[t]{5}{*}{ April } & $5^{\text {th }}$ week & 0.00 & 36.57 & 21.14 & 66.86 & 43.29 & 3.37 \\
\hline & $6^{\text {th }}$ week & 3.40 & 37.29 & 23.43 & 78.71 & 38.86 & 3.84 \\
\hline & $7^{\text {th }}$ week & 4.46 & 30.29 & 21.86 & 71.57 & 46.86 & 2.26 \\
\hline & $8^{\text {th }}$ week & 4.00 & 35.57 & 24.43 & 68.71 & 44.00 & 3.15 \\
\hline & $9^{\text {th }}$ week & 3.00 & 37.71 & 25.00 & 79.00 & 36.86 & 3.97 \\
\hline \multirow[t]{4}{*}{ May } & $10^{\text {th }}$ week & 1.00 & 38.43 & 25.14 & 78.00 & 35.57 & 4.27 \\
\hline & $11^{\text {th }}$ week & 0.86 & 37.43 & 25.29 & 76.86 & 46.57 & 3.36 \\
\hline & $12^{\text {th }}$ week & 0.00 & 39.00 & 25.86 & 79.14 & 55.71 & 3.10 \\
\hline & $13^{\text {th }}$ week & 3.36 & 38.43 & 26.43 & 80.29 & 52.86 & 3.13 \\
\hline \multirow[t]{4}{*}{ June } & $14^{\text {th }}$ week & 11.00 & 38.29 & 26.00 & 85.86 & 73.29 & 1.77 \\
\hline & $15^{\text {th }}$ week & 3.00 & 37.14 & 25.29 & 84.00 & 66.43 & 2.11 \\
\hline & $16^{\text {th }}$ week & 5.00 & 35.00 & 23.29 & 82.71 & 68.14 & 1.79 \\
\hline & $17^{\text {th }}$ week & 0.29 & 31.43 & 23.57 & 83.86 & 80.71 & 0.87 \\
\hline
\end{tabular}


Table.4 Estimates of GCA and SCA variances for various traits under heat stress condition

\begin{tabular}{|c|c|c|c|c|c|c|}
\hline \multirow[t]{2}{*}{ Characters } & \multicolumn{3}{|c|}{ Experiment-I (L×T) } & \multicolumn{3}{|c|}{ Experiment-II (NCD-II) } \\
\hline & $\sigma^{2}$ GCA & $\sigma^{2} \mathrm{SCA}$ & $\sigma^{2} \mathrm{GCA} / \sigma^{2} \mathrm{SCA}$ & $\sigma^{2} \mathrm{GCA}$ & $\sigma^{2} \mathrm{SCA}$ & $\sigma^{2} \mathrm{GCA} / \sigma^{2} \mathrm{SCA}$ \\
\hline Anthesis date & 0.05 & 0.79 & 0.06 & 0.08 & 1.93 & 0.04 \\
\hline Silking date & 0.01 & 0.35 & 0.02 & 0.04 & 1.70 & 0.02 \\
\hline Anthesis to silking interval & 0.03 & 0.24 & 0.12 & -0.09 & -0.13 & 0.69 \\
\hline Tassel blast (\%) & 5.91 & 131.52 & 0.04 & 4.36 & 19.90 & 0.21 \\
\hline Leaf firing (\%) & 0.60 & 20.93 & 0.03 & 1.72 & 2.38 & 0.72 \\
\hline Plant height (cm) & 2.36 & 5.61 & 0.42 & 1.50 & 3.40 & 0.44 \\
\hline Ear height (cm) & 0.30 & 4.52 & 0.06 & 1.10 & 6.62 & 0.16 \\
\hline Ear length (cm) & 0.02 & 0.79 & 0.02 & 0.034 & 0.06 & 0.56 \\
\hline Ear girth (cm) & 0.10 & 0.18 & 0.55 & 0.04 & 0.46 & 0.08 \\
\hline No. of grains per cob & 26.53 & 697.29 & 0.03 & 41.18 & 517.46 & 0.08 \\
\hline Shelling percentage $(\%)$ & 0.09 & 2.77 & 0.03 & 1.66 & 60.18 & 0.02 \\
\hline Test weight (g) & 0.06 & 0.21 & 0.28 & 0.23 & 0.90 & 0.25 \\
\hline Grain yield/plant (g) & 0.21 & 46.91 & 0.04 & 2.08 & 63.37 & 0.03 \\
\hline
\end{tabular}

Table.5 General combining ability ( $g c a$ ) effects of parents for various traits under heat stress condition

\begin{tabular}{|c|c|c|c|c|c|c|c|c|c|c|c|c|c|}
\hline Lines & AD & SD & ASI & TB & $\mathbf{L F}$ & PH & $\mathbf{E H}$ & EL & EG & NGC & SP & TW & GY \\
\hline \multicolumn{14}{|c|}{ Experiment-I $(\mathrm{L} \times \mathrm{T})$} \\
\hline L27 & -0.84 & 0.29 & 1.14 & 4.22 & -1.60 & 4.56 & $9.02 *$ & 0.39 & $0.97 * *$ & $71.60 * *$ & 0.77 & 2.58 & $33.64 * *$ \\
\hline L40 & 0.90 & -0.71 & -1.61 & 4.62 & -1.25 & $21.51 * *$ & $10.02 *$ & 0.96 & 0.57 & $55.85^{*}$ & -0.17 & -0.76 & 12.99 \\
\hline L28 & L28 & $-2.59 * *$ & -0.46 & $-2.14 *$ & $-14.09 *$ & 2.69 & 4.01 & 1.62 & -0.66 & -0.52 & 4.10 & -6.36 & -2.01 \\
\hline$\overline{T 1}$ & $1.26 * *$ & 0.36 & $-0.90 * *$ & $-20.57 * *$ & 1.50 & $9.57 * *$ & 1.37 & 0.19 & 0.32 & $-41.43 * *$ & -0.25 & $1.76 * *$ & 1.42 \\
\hline \multicolumn{14}{|c|}{ Experiment-II (NCD-II) } \\
\hline L2 & L2 & 0.72 & 0.98 & 0.25 & $-8.11 *$ & -5.78 & -0.64 & 1.88 & 0.39 & 0.40 & -24.23 & 0.27 & -0.08 \\
\hline $\mathbf{L 7}$ & L7 & 0.15 & 0.62 & 0.47 & 3.42 & 3.22 & -2.33 & 3.42 & 0.12 & -0.55 & -14.80 & $3.98 *$ & 2.05 \\
\hline T6 & T6 & 0.08 & 0.76 & 0.68 & -4.54 & -2.80 & -0.01 & 1.12 & $1.16^{* * *}$ & 0.40 & 29.40 & -0.67 & 0.71 \\
\hline
\end{tabular}

* and **Significance at $\mathrm{p}=0.05$ and $\mathrm{p}=0.01$, respectively. $\mathrm{AD}-$ Anthesis date, SD- Silking date, ASI- Anthesis to silking interval, $\mathrm{TB}-\mathrm{Tassel}$ balst $(\%), \mathrm{LF}-$ Leaf firing (\%), PH - Plant height $(\mathrm{cm})$, EH- Ear height $(\mathrm{cm})$, EL -Ear length $(\mathrm{cm})$, EG - Ear girth $(\mathrm{cm})$, NGC- No. of grains per cob, SP-Shelling \%, TW Test weight (g), GY - Grain yield per plant (g) 
Table.6 Specific combing ability ( $s c a$ ) effects of top three crosses for different characters in desirable directions under heat stress condition (NCD-II)

\begin{tabular}{|c|c|c|c|c|}
\hline & \multicolumn{2}{|c|}{ Experiment-I $(L \times T)$} & \multicolumn{2}{|c|}{ Experiment-II (NCD-II) } \\
\hline Characters & Crosses & sca effects & Crosses & sca effects \\
\hline \multirow{2}{*}{ Anthesis to silking interval } & L6 x T2 & $-2.65^{*}$ & L1 x T5 & $-3.54 *$ \\
\hline & L14 x T1 & -1.85 & $\mathrm{~L} 4 \times \mathrm{T} 4$ & -2.04 \\
\hline \multirow[t]{3}{*}{ Tassel blast (\%) } & $\mathrm{L} 22 \times \mathrm{T} 2$ & $-33.12 * *$ & L2 x T1 & -17.83 \\
\hline & $\mathrm{L} 2 \times \mathrm{T} 2$ & $-20.31^{*}$ & L6 x T6 & -15.37 \\
\hline & $\mathrm{L} 20 \times \mathrm{T} 2$ & $-20.24 *$ & L7 x T5 & -13.02 \\
\hline \multirow{2}{*}{ Leaf firing (\%) } & $\mathrm{L} 22 \times \mathrm{T} 2$ & $-16.86^{*}$ & L2 x T1 & -9.98 \\
\hline & $\mathrm{L} 36 \times \mathrm{T} 2$ & -10.75 & L1 x T5 & -8.35 \\
\hline \multirow[t]{3}{*}{ Plant height $(\mathbf{c m})$} & L14 x T1 & 10.18 & L7 x T1 & $18.31 *$ \\
\hline & $\mathrm{L} 24 \times \mathrm{T} 2$ & 9.32 & L3 x T6 & 16.83 \\
\hline & $\mathrm{L} 33 \times \mathrm{T} 2$ & 8.57 & L1 x T2 & 12.63 \\
\hline \multirow[t]{3}{*}{ No. of grains per cob } & $\mathrm{L} 25 \times \mathrm{T} 2$ & $78.81^{*}$ & L2 x T4 & 88.02 \\
\hline & $\mathrm{L} 28 \times \mathrm{T} 1$ & 67.69 & L4 x T6 & 73.59 \\
\hline & $\mathrm{L} 42 \times \mathrm{T} 2$ & 57.31 & L7 x T1 & 71.95 \\
\hline \multirow{2}{*}{ Test weight (g) } & $\mathrm{L} 41 \times \mathrm{T} 2$ & 4.36 & L6 x T5 & $4.68 *$ \\
\hline & $\mathrm{L} 14 \times \mathrm{T} 2$ & 3.96 & L7 x T1 & 3.68 \\
\hline \multirow{3}{*}{ Grain yield per plant $(\mathrm{g})$} & L28 x T1 & $27.21 *$ & L4 x T6 & $30.81 * *$ \\
\hline & $\mathrm{L} 18 \times \mathrm{T} 1$ & 20.99 & L6 x T4 & $27.83^{* *}$ \\
\hline & $\mathrm{L} 22 \times \mathrm{T} 2$ & 18.78 & L7 x T1 & $24.93^{*}$ \\
\hline
\end{tabular}

* and **Significance at $\mathrm{p}=0.05$ and $\mathrm{p}=0.01$, respectively.

Table.7 Association of selected traits for tropical maize under heat stress condition of experiment-I (LxT) and experiment-II (NCD-II)

\begin{tabular}{|c|c|c|c|c|c|c|}
\hline & ASI & Tassel blast \% & Leaf firing \% & Plant height (cm) & NGC & Yield per plant (g) \\
\hline ASI & 1 & 0.058 & 0.086 & -0.102 & -0.097 & -0.113 \\
\hline Tassel blast \% & $0.276^{*}$ & 1 & $0.934 *$ & $-0.220^{*}$ & 0.193 & -0.152 \\
\hline Leaf firing \% & 0.114 & 0.133 & 1 & 0.186 & 0.171 & -0.163 \\
\hline Plant height (cm) & $-0.341 *$ & $-0.333^{*}$ & $-0.203^{*}$ & 1 & 0.088 & $0.286^{*}$ \\
\hline NGC & $0.238^{*}$ & $0.280 *$ & 0.060 & 0.261 & 1 & $0.453^{*}$ \\
\hline Yield per plant (g) & -0.107 & $-0.165^{*}$ & -0.025 & $0.199 *$ & $0.458^{*}$ & 1 \\
\hline
\end{tabular}

* and **Significance at $\mathrm{p}=0.05$ and $\mathrm{p}=0.01$, respectively.

Note: Values below the diagonal are the results from $\mathrm{L} \times \mathrm{T}$ (experiment-I) and values above the diagonal are the results from NCD-II (experiment-II) 
Another hybrid, VL062655 × CAL14113 exhibited highly significant sca effects for number of grains per cob (73.59) and grain yield (30.86). VL1010963 × CIL1218 combination was desirable for ASI (-3.54), which is an important trait for getting high yield under heat stress condition. Dinesh et al., (2016) identified good general and specific combiners for heat stress tolerance from his studies.

\section{Association of selected traits under heat stress condition}

The association of traits under heat stress condition indicated that important heat tolerant traits viz., tassel blast and leaf firing exhibited negative association with yield and yield contributing traits (Table 7). Yield per plant was negatively associated with the tassel blast (-0.165) in Experiment-I. Leaf firing and tassel blast showed negative significant correlation with plant height in experiment-I $(-0.333,-0.203)$ but in experiment-II, only tassel blast showed negative association with plant height (-0.220). The negative association of grain yield with tassel blast was also reported by Rupinderkaur et al., (2010). Further, plant height was positively correlated with grain yield $(0.199,0.286)$ under heat stress. Thus, as the heat stress increases substantially, plant height decreases as a result there is significant decrease in grain yield. Tassel blast showed significant positive correlation with leaf firing $(0.133,0.934)$ indicating the expression of these two traits together under heat stress condition. Another yield attributing trait i.e., number of grains per cob $(0.458,0.453)$ exhibited significant positive association with yield in both the experiments and proved that it is an important trait to determine the grain yield under heat stress. Dinesh et al., (2016) Jodage et al., (2017) reported that plant height, ear height, number of kernels per cob and shelling per cent were positively associated with grain yield and ASI was negatively associated with grain yield under heat stress.

From the present study, it is confirmed that most of the traits of tropical maize under heat stress conditions are controlled by nonadditive gene action. The traits viz., plant height and number of grains per cob could be considered as positive traits and tassel blast and leaf firing could be considered as negative traits while selecting tropical maize lines /hybrids for heat stress tolerance, as they exhibited positive and negative associations with grain yield under heat stress, respectively. Further, in both the experiments, parents with desirable gca effects and potential hybrids with desirable sca effects for heat tolerance as well as yield traits were identified.

\section{Acknowledgement}

This study was carried out as an objective under the Heat stress tolerant maize for Asia (HTMA) Project funded by the United States Agency for International Development (USAID). The funding from USAID is gratefully acknowledged. Staff-time of the coauthors (PHZ and MTV) supported by CGIAR Research Program on MAIZE Agrifood system is duly acknowledged.

\section{References}

Abrha, S.W., Zeleke H. Z. and Gissa, D.W. 2013. Line $\times$ tester analysis of maize inbred lines for grain yield and yield related traits. Asian J. of Plant Sci. Res., 3(5): 12-19

Abtew, W. and Melesse, A. 2013. Evaloration and evapotranspiration: Measurements and estimations. DOI: 10.1007/978-94-007-4737-1.

Al-Jibouri, H. A., Miller, P. A. and Robinson, H. F. 1958 Genotypic and environmental variances in upland cotton of inter-specific origin. Agron. J., 50: 633-637.

Cairns, J. E., Sonder, K., Zaidi, P. H., Verhulst, P. N., Mahuku, G., Babu, R., Nair, S. K., Das, B., Govaerts, B., Vinayan, M. T., Rashid, Z., 
Noor, J. J., Devi, P., Vicente, F. S. and Prasanna, B. M. 2012. Maize production in a changing climate: Impacts, adaptation, and mitigation strategies. Advances in Agron., 114: $1-65$.

Cantarero, M. G., Cirilo, A. G. and Andrade, F. H. 1999. Night temperature at silking affects kernel set in maize. Crop Sci., 39(3):701-710.

Chen, J. Xu. W., Burke, J. J. and Xin, Z. 2010. Role of phosphatidic acid in high temperature tolerance in maize. Crop Sci., 50: 2506-2515

Chen, J. Xu. W., Velten, J., Xin, Z. and Stout, J. 2012. Characterization of maize inbred lines for drought and heat tolerance. J. of soil and water Conservation, 67(5): 354-364

Christensen, J. H. and Christensen, O. B. 2007. A summary of the PRUDENCE model projections of changes in European climate by the end of this century. Clim. change 81: 7-30

Comstock, R. E. and Robinson, H. F. 1952. Estimation of average dominance of genes. In: Heterosis. Gowen, J.W. (Ed.). Iowa State University Press Ames, Iowa, USA: 494-516.

Dinesh, A., Patil, A., Zaidi, P. H., Kuchanur, P. H., Vinayan, M. T. and Seethram, K. 2016. Line $\times$ testers analysis of tropical maize inbred lines under heat stress for grain yield and secondary traits. Maydica, 61: 135-139.

Dinesh, A., Patil, A., Zaidi, P. H., Kuchanur, P. H., Vinayan, M. T. and Seethram, K. And Amaregouda. 2016. Dissection of heat tolerance mechanism in tropical maize. Res. on Crops, 17 (3): 462-467.

FAOSTAT (Food and Agriculture Organization of the United Nations Statistics Division). (20062008) http:// faostat.fao.org/default.aspx.

Jodage, K., Kuchanur, P.H., Zaidi, P.H., Ayyanagouda, P., Seetharam. K., Vinayan, M.T. and Arunkumar, M.T. 2017. Association and path analysis for grain yield and its attributing traits under heat stress condition in tropical maize (Zea mays L.). Electronic J. Pl. Breed., 8(1): 336-341.

Kempthorne, O. 1957. "An introduction to genetic statistics", John Wiley and Sons, New York.

Lobell, D. B., Banziger, M., Magorokosho, C. and Vivek, B. 2011. Nonlinear heat effects on African maize as evidenced by historical yield trials. Nature Clim. Change. 1: 42-45.

Rowhani. P., Lobell, D. B., Linderman, M. and Ramankutty N., 2011. Climate variability and crop production in Tanzania. Agriculture and Forest Meteorology 151: 449-460.

Rupinderkaur, Saxena, V. K. and Malhi, N. S. 2010. Combining ability for heat tolerance traits in spring maize (Zea mays L.). Maydica, 55: 195-199.

Shaw, R. H. 1983. Estimates of yield reductions in corn caused by water and temperature stress. In Crop Relations to Water and Temperature Stress in Humid Temperate Climates, eds. C.D. Ruper, Jr. and P.J. Kramer, 49-66. Boulder, CO: Westview Press.

Tassawer, H., Ahmedkhan, I., Malik, M. A. and Ali, Z. 2007. Study on gene action and combining abilities for thermotolerant ablilities of corn (Zea mays L.) Pakistan J. of Bot., 38(4): 1185-1195

Wilhelm, E. P., Mullen, R. E., Keeling, P. L. and Singletary, G. W. 1999. Heat stress during grain filling in maize: Effects on kernel growth and metabolism. Crop Sci., 39(6):1733-1741.

Zaidi, P. H., Zaman-Allah M., Trachsel, S., Seetharam, K., Cairns, J. E. and Vinayan, M. T. 2016. Phenotyping for abiotic stress tolerance in maize - Heat stress. A field manual. CIMMYT: Hyderabad, India.

\section{How to cite this article:}

Krishnaji Jodage, P.H. Kuchanur, P.H. Zaidi, Ayyanagouda Patil, K. Seetharam, M.T. Vinayan and Arunkumar, B. 2018. Genetic Analysis of Heat Adaptive Traits in Tropical Maize (Zea mays L.). Int.J.Curr.Microbiol.App.Sci. 7(01): 3237-3246.

doi: https://doi.org/10.20546/ijcmas.2018.701.387 